\title{
LOAD FREQUENCY CONTROL OF TWO AREA POWER SYSTEM WITH INTEGRAL PROPORTIONAL-INTEGRAL AND PID CONTROLLER
}

\author{
Jasmendra Singh ${ }^{1}$ \\ ${ }^{l}$ M.Tech in Power System from Department of EE, MNIT Jaipur, India
}

\begin{abstract}
This paper has discussion on two area load frequency control with Integral (I), Proportional Integral (PI) and ProportionalIntegral-Derivative (PID) controller. This is basic paper on two area load frequency control which presents comparative analysis of these controllers with the effects of gain factors of these controllers on frequency deviation. First, system is discussed with and without integral controller then I is replaced with PI \& after that with PID to get the results from these controllers to make the comparative analysis. Analysis is based on MATLAB/SIMULINK 2010 a.
\end{abstract}

Keywords-Two-area, Integral (I) Controller Proportion-Integral (PI) Controller, Proportional-Integral-Derivative (PID) Controller, Load Frequency Control (LFC), Area Control Error (ACE), Tie-line Power Deviation, Frequency Deviation

\section{INTRODUCTION}

Load is not constant on any power system. Its variation takes place with time. Frequency deviation results from active power mismatch in the system and voltage variation results from reactive power mismatch in the system. Performance of many machines deteriorates when frequency differs from nominal value. It can be observed that during load disturbance system frequency goes down, under such conditions there is need to increase real power generation. For increasing real power generation some constraints known as generation rate constrains, are also taken into account. For reliable system operation frequency variation limit is $+/-0.5 \mathrm{~Hz}$ [2]. When load side real power demand dominates the generation side real power then frequency comes down from its nominal value at generation side and vice-versa. When real power generation equalizes to active load demand plus losses then system operates at its nominal frequency. Change in active power generation is done at generation side, only under emergency conditions it is done at load side [7]. In case of interconnected systems, whenever there is load disturbance in any area then power flows from other areas to supply the demand which helps in reduction of frequency deviation of that particular area in which disturbance has occurred. Proportional-integral-derivative controller (PID) is effective in reducing transients during disturbance along with overshoots [3]. For the ease of analysis an equivalent governor, an equivalent turbine and an equivalent generator load model is used for the entire system which is known by a particular area, e.g. area-1.

\section{TWO AREA SYSTEM}

A two area system has two areas connected through a tieline. Area-1 represents equivalent governor, turbine and generator load model of the entire system. Area-2 represents equivalent model of another entire system. Tie-line power flows due to frequency deviations. For any load change, all the generating units respond simultaneously to maintain coherency. This type of coherent area is known as control area where frequency is same under both static and dynamic conditions. Fig.1 shows the block diagram of two area power system without integral controller and Fig.2 shows the block diagram of two area system with integral controller. System should be operated around nominal frequency because [8] -

1. Three phase AC motors will not give good performance as their speed directly depends on the frequency.

2. Turbine blades are likely to be damaged if frequency goes beyond specified limits [47.5 52.5].

3. Electric clocks are operated by synchronous motors. Clocks will give error for any deviation in the frequency.

4. Saturation problem will arise in power transformers under constant voltage mode operation if frequency goes down.

5. Blast of fans like ID \& FD in a thermal plant causes reduction in generation for which proper load shedding is required otherwise it is likely to shut down. 


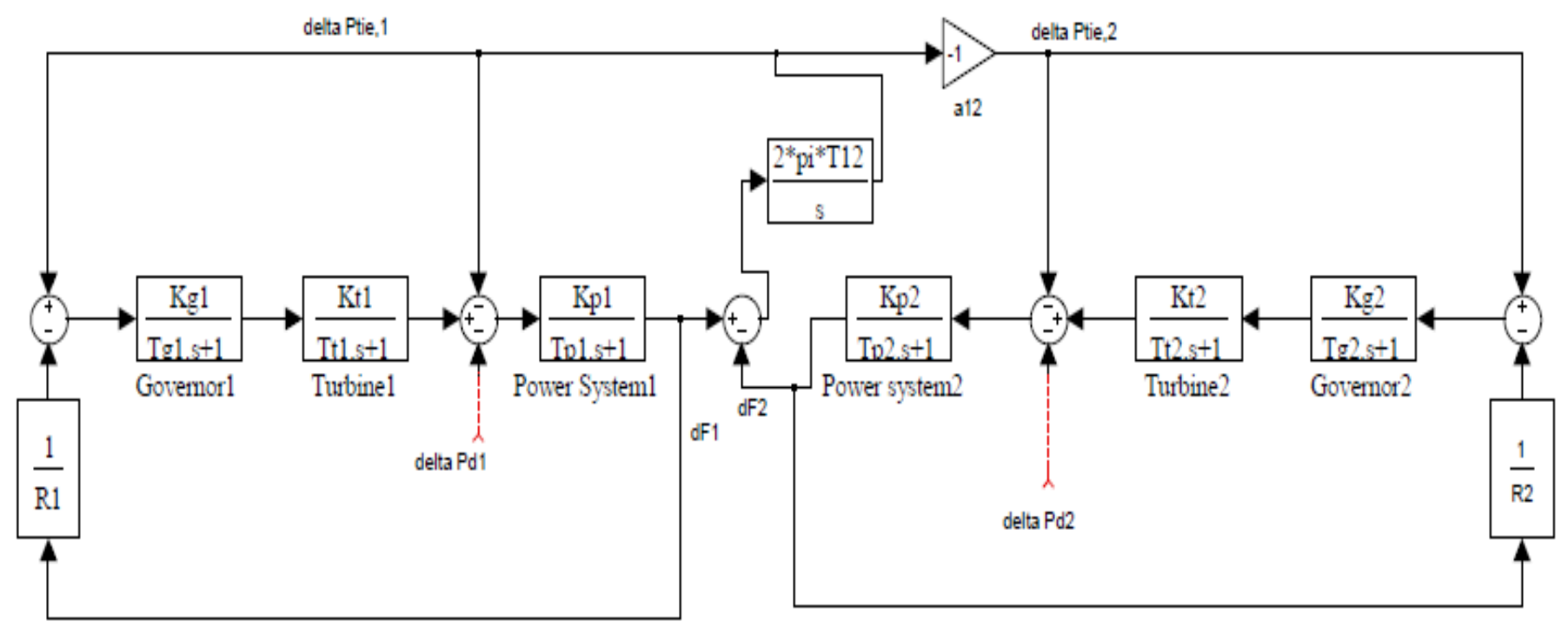

Fig.1: Block diagram of two area system without integral controller

It is assumed that area-1 has surplus power. Therefore, power out of area- 1 can be given as-

$$
\mathrm{P}_{\text {tie, }, 1}=\left(\left|\mathrm{V}_{1} \| \mathrm{V}_{2}\right| / \mathrm{X}_{12}\right) \operatorname{Sin}\left(\delta_{1}-\delta_{2}\right)
$$

Here $\delta_{1}, \delta_{2}$ are angles of $\mathrm{V}_{1}$ and $\mathrm{V}_{2}$ which are end voltages of equivalent machines of area-1 and area- 2 respectively.

For $\Delta \mathrm{f}_{1}$ and $\Delta \mathrm{f}_{2}$, change in tie-line power can be given by [2]-

$\Delta \mathrm{P}_{\mathrm{tie}, 1}(\mathrm{pu})=2 \Pi \mathrm{T}_{12}\left(\int \Delta \mathrm{f}_{1} \mathrm{dt}-\int \Delta \mathrm{f}_{2} \mathrm{dt}\right)$

$\Delta \mathrm{P}_{\mathrm{tie}, 2}(\mathrm{pu})=2 \Pi \mathrm{T}_{21}\left(\int \Delta \mathrm{f}_{2} \mathrm{dt}-\int \Delta \mathrm{f}_{1} \mathrm{dt}\right)$

Synchronizing coefficients $\mathrm{T}_{12}$ and $\mathrm{T}_{21}$ are given as [2]-

$\mathrm{T}_{12}=\left(\left|\mathrm{V}_{1} \| \mathrm{V}_{2}\right| /\left(\mathrm{P}_{\mathrm{r} 1} \mathrm{X}_{12}\right)\right) \operatorname{Cos}\left(\delta_{1}-\delta_{2}\right)$
$\mathrm{T}_{21}=\left(\left|\mathrm{V}_{1} \| \mathrm{V}_{2}\right| /\left(\mathrm{P}_{\mathrm{r} 2} \mathrm{X}_{21}\right)\right) \operatorname{Cos}\left(\delta_{2}-\delta_{1}\right)=\left(\mathrm{P}_{\mathrm{r} 1} / \mathrm{P}_{\mathrm{r} 2}\right) \mathrm{T}_{12}=-\mathrm{a}_{12} \mathrm{~T}_{12}$, $\mathrm{a}_{12}=\left(-\mathrm{P}_{\mathrm{r} 1} / \mathrm{P}_{\mathrm{r} 2}\right)$

$\mathrm{P}_{\mathrm{r} 1}$ is rated power (MW) of area-1 and $\mathrm{P}_{\mathrm{r} 2}$ is rated power (MW) of area-2. Base power is given in MVA.

Tie-line power deviations are given as [2]-

$\Delta \mathrm{P}_{\text {tie }, 1}(\mathrm{~s})=\left(2 \Pi \mathrm{T}_{12} / \mathrm{s}\right)\left[\Delta \mathrm{F}_{1}(\mathrm{~s})-\Delta \mathrm{F}_{2}(\mathrm{~s})\right]$

$\Delta \mathrm{P}_{\text {tie }, 2}(\mathrm{~s})=\mathrm{a}_{12}\left(-2 \Pi \mathrm{T}_{12} / \mathrm{s}\right)\left[\Delta \mathrm{F}_{1}(\mathrm{~s})-\Delta \mathrm{F}_{2}(\mathrm{~s})\right]$

Area control errors for area-1 and area-2 are given as [2]-

$\mathrm{ACE}_{1}(\mathrm{~s})=\Delta \mathrm{P}_{\text {tie, } 1}(\mathrm{~s})+\mathrm{b}_{1} \Delta \mathrm{F}_{1}(\mathrm{~s})$

$\mathrm{ACE}_{2}(\mathrm{~s})=\Delta \mathrm{P}_{\mathrm{tie}, 2}(\mathrm{~s})+\mathrm{b}_{2} \Delta \mathrm{F}_{2}(\mathrm{~s})$ where $\mathrm{b}_{1}, \mathrm{~b}_{2}$ are frequency bias constants.

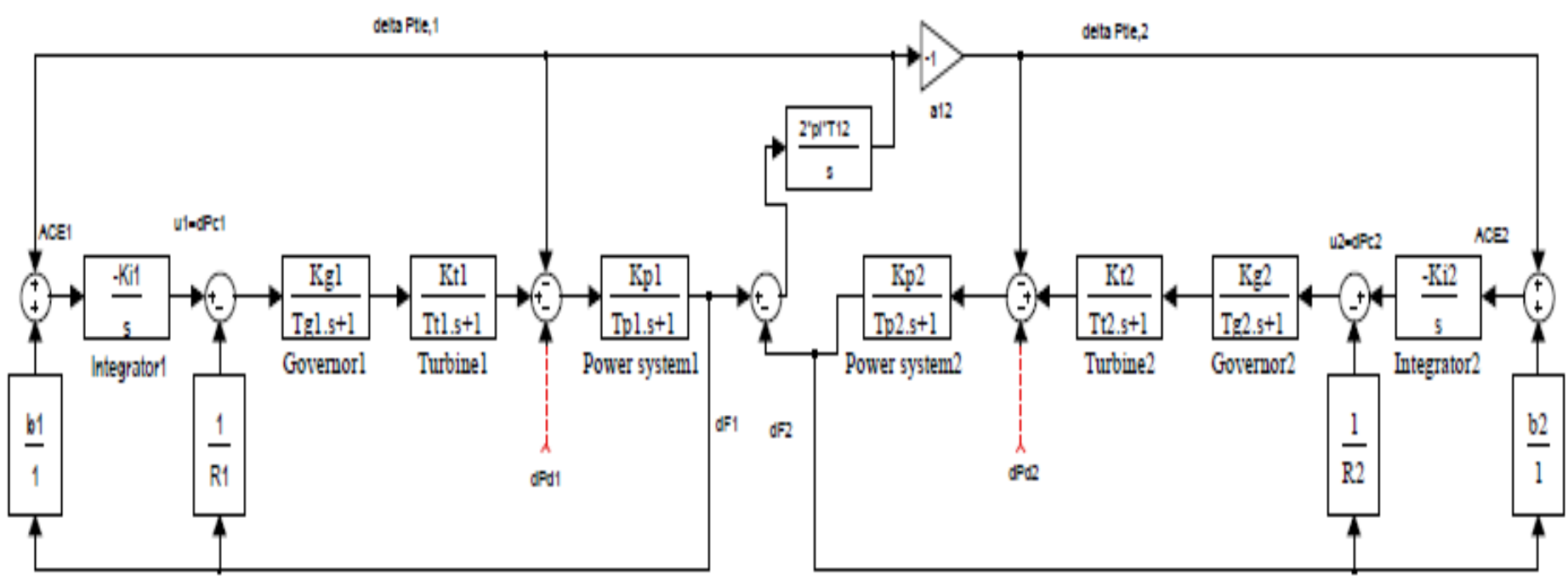

Fig.2: Block diagram of two area system with integral controller 
Frequency deviations can be written as [2]-

$\Delta \mathrm{F}_{1}(\mathrm{~s})=\left[\Delta \mathrm{P}_{\mathrm{G} 1}(\mathrm{~s})-\Delta \mathrm{P}_{\mathrm{D} 1}(\mathrm{~s})-\Delta \mathrm{P}_{\text {tie, } 1}(\mathrm{~s})\right] \mathrm{K}_{\mathrm{p} 1} /\left(1+\mathrm{T}_{\mathrm{P} 1} \mathrm{~s}\right)$

$\Delta \mathrm{F}_{2}(\mathrm{~s})=\left[\Delta \mathrm{P}_{\mathrm{G} 2}(\mathrm{~s})-\Delta \mathrm{P}_{\mathrm{D} 2}(\mathrm{~s})-\Delta \mathrm{P}_{\text {tie, }, 2}(\mathrm{~s})\right] \mathrm{K}_{\mathrm{p} 2} /\left(1+\mathrm{T}_{\mathrm{P} 2} \mathrm{~s}\right)$

Where $K_{p}=1 / B=$ Power system gain and $T_{p}=2 H /(B f)=$ Power system time constant.

\section{PID CONTROL}

Transfer function of PID controller can be written as-

$$
\mathrm{G}(\mathrm{s})=\mathrm{K}_{\mathrm{p}}+\mathrm{K}_{\mathrm{i}} / \mathrm{s}+\mathrm{K}_{\mathrm{d}} \cdot \mathrm{s}
$$

Gain $\mathrm{K}_{\mathrm{p}}$ affects mainly overshoot, $\mathrm{K}_{\mathrm{i}}$ affects mainly settling time \& it can also be observed that when overshoot reduces then settling time increases with I and PI. $\mathrm{K}_{\mathrm{d}}$ has impact on both overshoot and transients. Integral controller has only one gain $\mathrm{K}_{\mathrm{i}}$ and its value can be obtained by trial \& error method. When gain $K_{p}$ is introduced along with $K_{i}$ then it becomes PI controller $\left(K_{p}+K_{i} / s\right)$. When we go I to PI then overshoot reduces but settling time increases. PI is reduced form of PID. In PID controller due to damping factor $K_{d}$, it gives least overshoot, least settling time and least transients among these controllers with proper tuning of parameters. These three controllers provide their best results only at a particular operating point corresponding to given system parameters with the chosen gain factors $\left(\mathrm{K}_{\mathrm{p}}, \mathrm{K}_{\mathrm{i}}, \mathrm{K}_{\mathrm{d}}\right)$. Under dynamic conditions it may be that system parameters are different, in that case these controllers don't provide their best results. To overcome this type of problems, fuzzy logic based controllers are in use these days where system robustness and reliability are more important. With these controllers (I, PI, PID) due to introduction of a pole at origin by the term $1 / \mathrm{s}$, steady state error is reduced. In PID controller due to derivative term, a zero is added in the open loop transfer function. It helps in the reduction of both transients and overshoots with proper tuning of all the parameters of the controller [3]. Tuning of parameters can be done easily by trial \& error method using permutationcombinations. In case of integral controller, $\mathrm{K}_{\mathrm{i}}$ should be less than its critical value for damped and non-oscillatory response. Critical value of gain is given by-

$$
\mathrm{K}_{\mathrm{crit}}=(1 / 4) \mathrm{T}_{\mathrm{ps}} \mathrm{K}_{\mathrm{ps}}\left(1+\mathrm{K}_{\mathrm{ps}} / \mathrm{R}\right)^{2}=\text { Critical value of gain }
$$

Area control error (ACE) is the input to each controller and real power command signal $\Delta \mathrm{P}_{\mathrm{C}}$ is obtained after the controller action which is input to the speed changer of that area. For Integral controller-

$$
\Delta \mathrm{P}_{\mathrm{C} 1}=-\mathrm{K}_{\mathrm{i} 1} \int\left(\mathrm{ACE}_{1}\right) \mathrm{dt} \quad \& \quad \Delta \mathrm{P}_{\mathrm{C} 2}=-\mathrm{K}_{\mathrm{i} 2} \int\left(\mathrm{ACE}_{2}\right) \mathrm{dt}
$$

For PI controller-

$$
\Delta \mathrm{P}_{\mathrm{C} 1}=\mathrm{K}_{\mathrm{p} 1}+\mathrm{K}_{\mathrm{i} 1} \int\left(\mathrm{ACE}_{1}\right) \mathrm{dt} \quad \& \Delta \mathrm{P}_{\mathrm{C} 2}=\mathrm{K}_{\mathrm{p} 2}+\mathrm{K}_{\mathrm{i} 2} \int\left(\mathrm{ACE}_{2}\right) \mathrm{dt}
$$

For PID controller-

$$
\begin{aligned}
& \Delta \mathrm{P}_{\mathrm{C} 1}=\mathrm{K}_{\mathrm{p} 1}+\mathrm{K}_{\mathrm{i} 1} \int\left(\mathrm{ACE}_{1}\right) \mathrm{dt}+\mathrm{K}_{\mathrm{d} 1} \mathrm{~d}\left(\mathrm{ACE}_{1}\right) / \mathrm{dt} \\
& \Delta \mathrm{P}_{\mathrm{C} 2}=\mathrm{K}_{\mathrm{p} 2}+\mathrm{K}_{\mathrm{i} 2} \int\left(\mathrm{ACE}_{2}\right) \mathrm{dt}+\mathrm{K}_{\mathrm{d} 2} \mathrm{~d}\left(\mathrm{ACE}_{2}\right) / \mathrm{dt}
\end{aligned}
$$

Where $\Delta \mathrm{P}_{\mathrm{C} 1}, \Delta \mathrm{P}_{\mathrm{C} 2}$ are real power command signals of area-1 and area-2 respectively. Ki1 \& $\mathrm{Ki} 2$ are integral gains, $\mathrm{K}_{\mathrm{p} 1}$ \& $\mathrm{K}_{\mathrm{p} 2}$ are proportional gains and $\mathrm{K}_{\mathrm{d} 1}, \mathrm{~K}_{\mathrm{d} 2}$ are derivative gains of area-1 \& area-2 respectively.

\section{SIMULATION \& RESULTS}

Simulation model of the system without Integral controller is shown in Fig. 3 and Fig.4 shows the simulation model of the system with integral controller. For a step load disturbance of $0.05 \mathrm{pu}$ in area-1, these results were obtained for the given controllers. Fig.5 to Fig.7 show the frequency deviation and Fig.8 to Fig.10 show incremental turbine power outputs $\left(\Delta \mathrm{P}_{\mathrm{m} 1}, \Delta \mathrm{P}_{\mathrm{m} 2}\right)$ and tie-line power deviations with the given controllers.

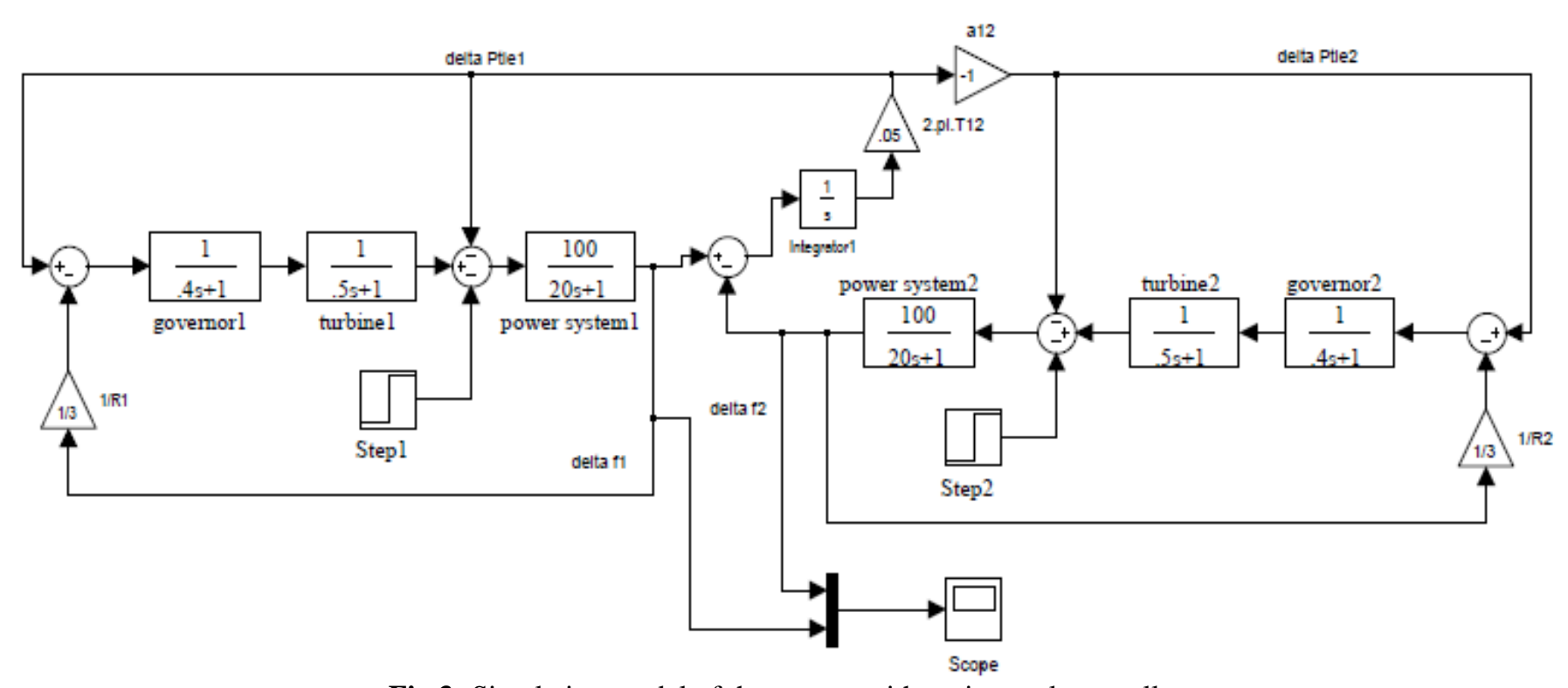

Fig.3: Simulation model of the system without integral controller 


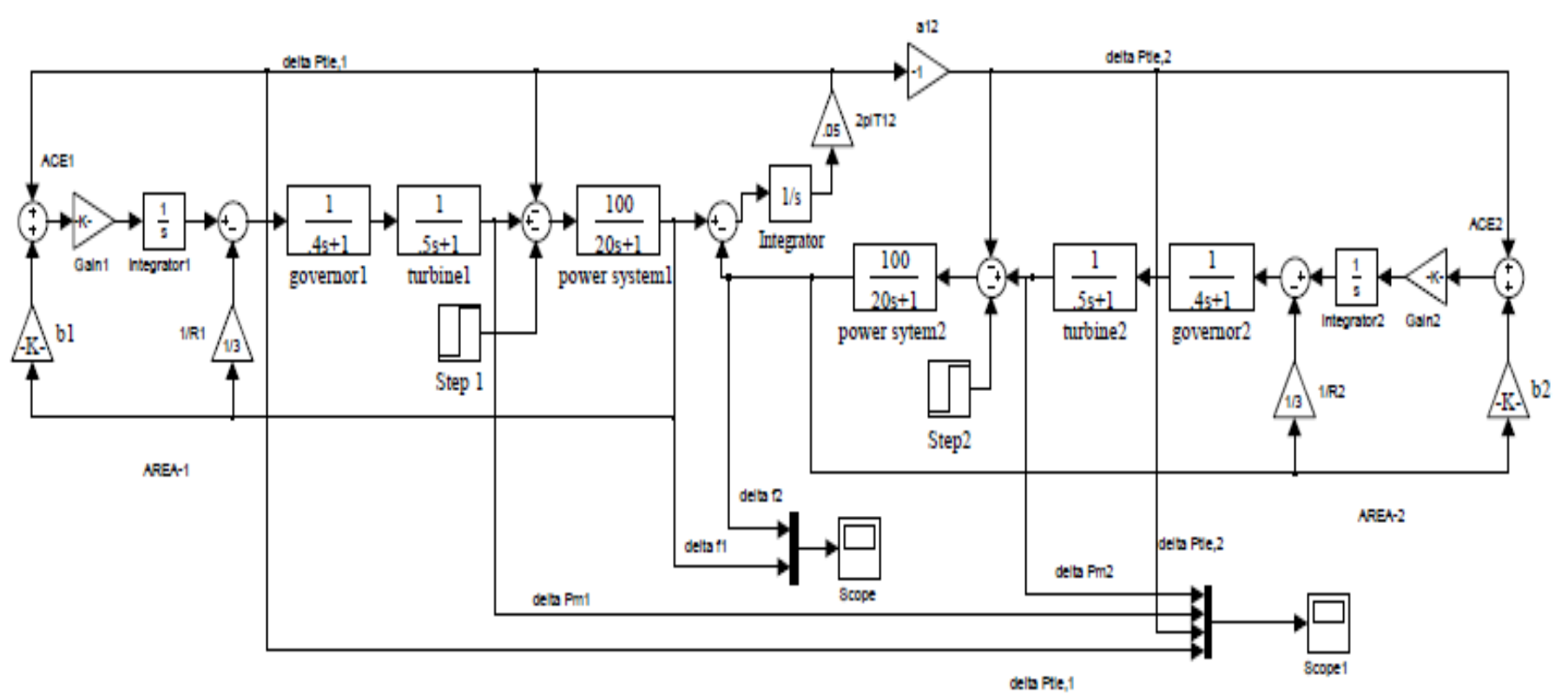

Fig.4: Simulation model of the system with integral controller

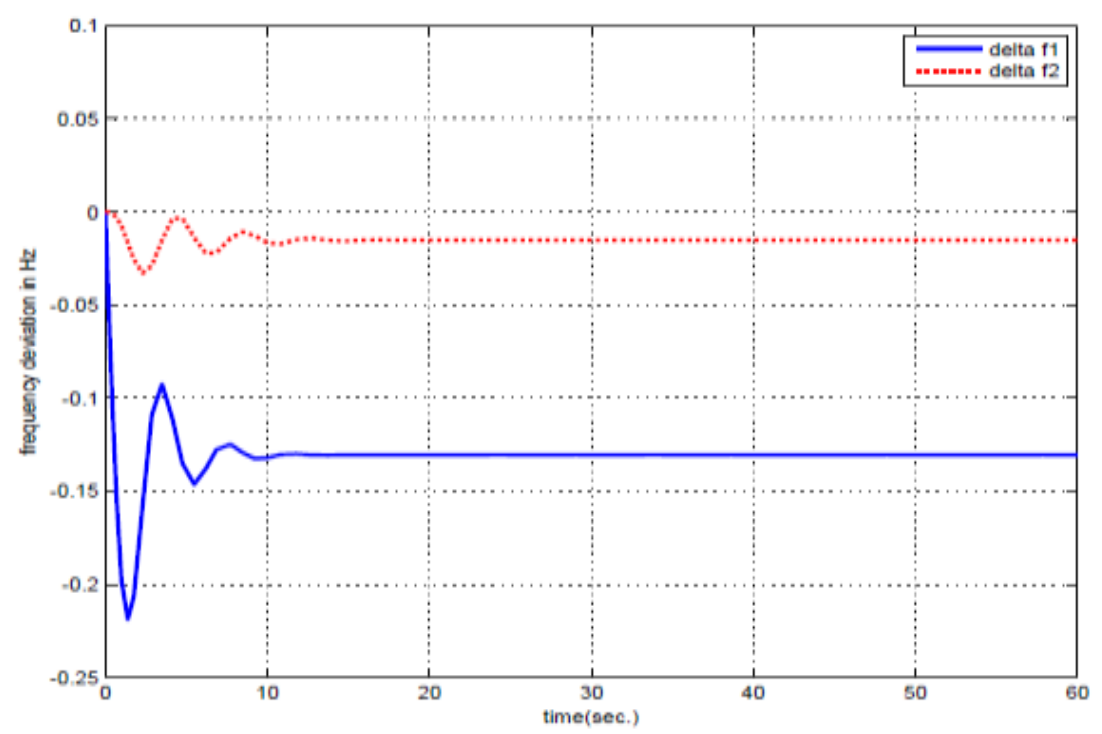

Fig.5: Frequency deviation v/s time without I controller

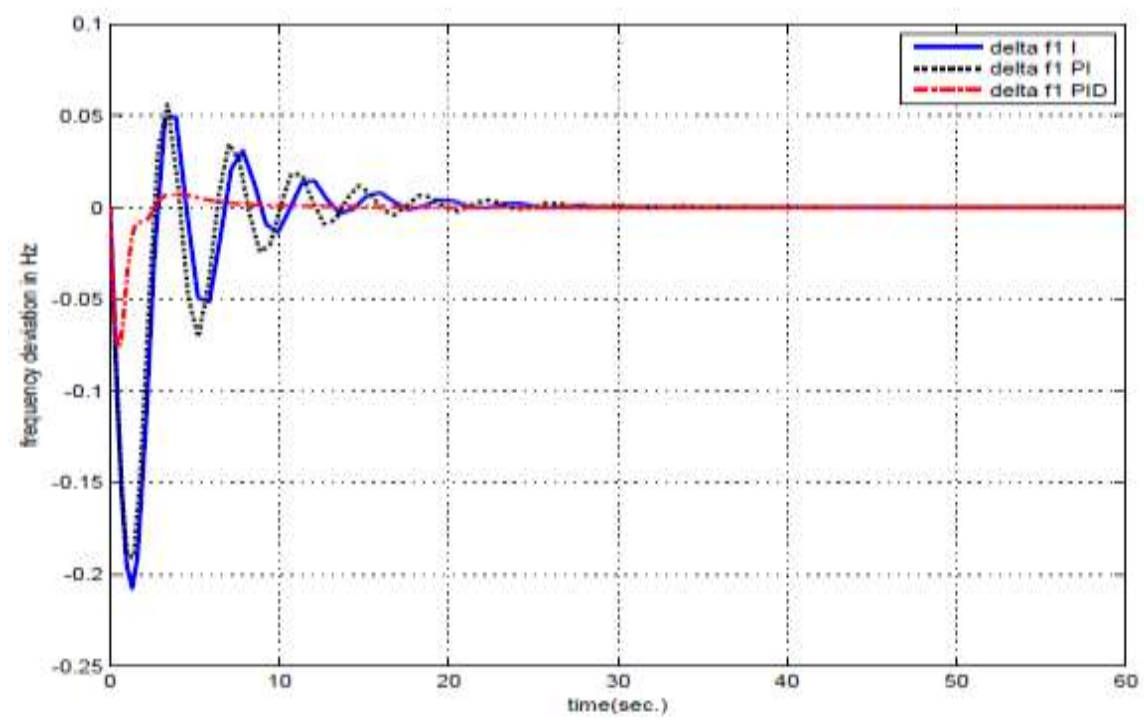

Fig.6: Frequency deviation v/s time for area-1 


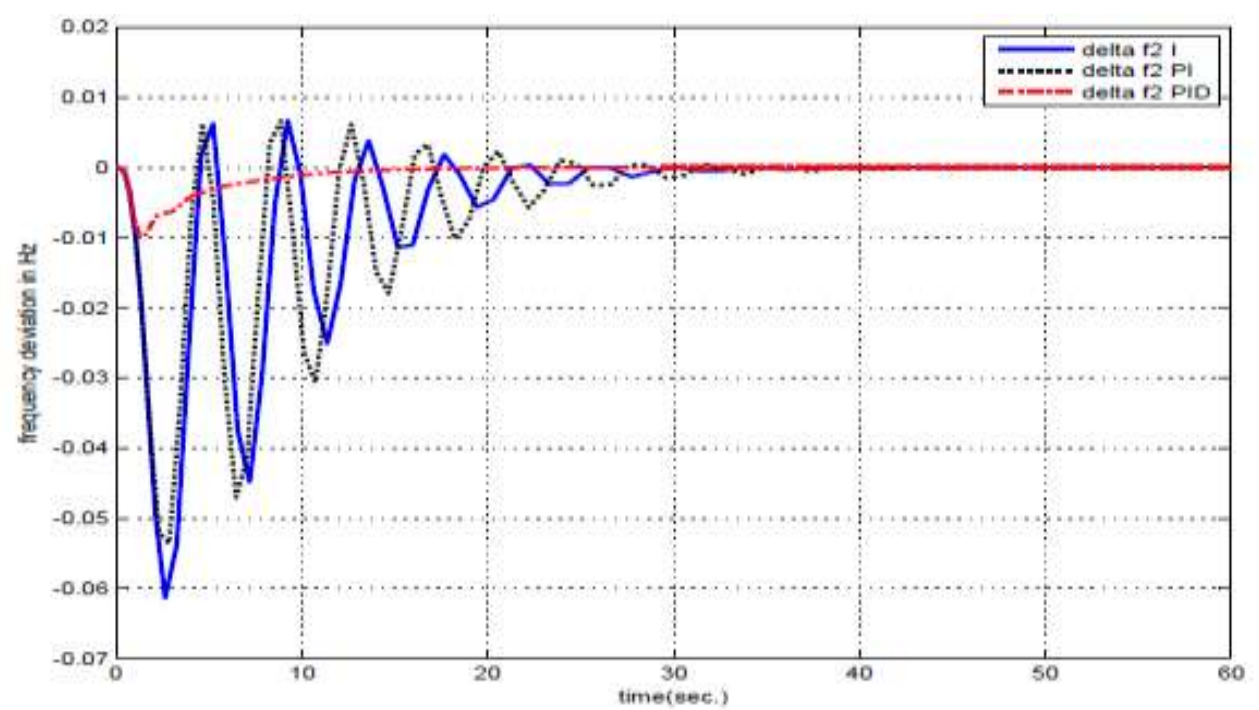

Fig.7: Frequency deviation v/s time for area-2

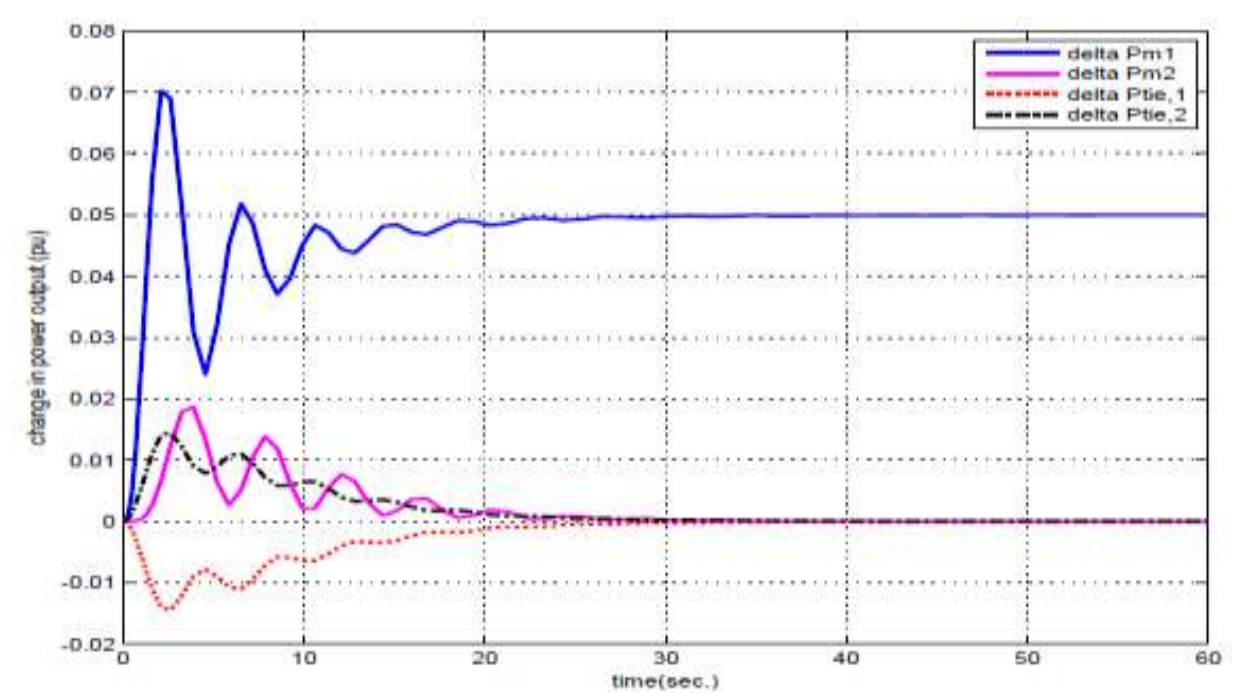

Fig.8: Change in power output v/s time with I

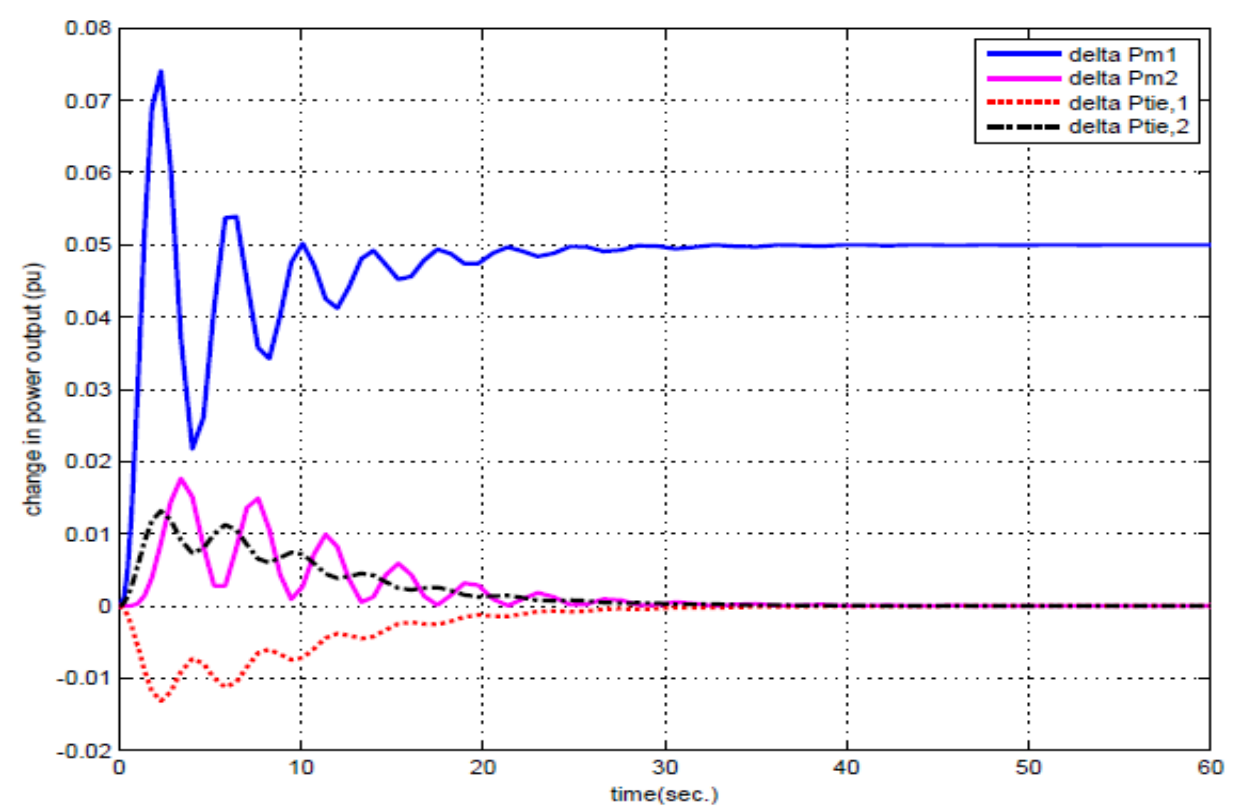

Fig.9: Change in power output v/s time with PI 


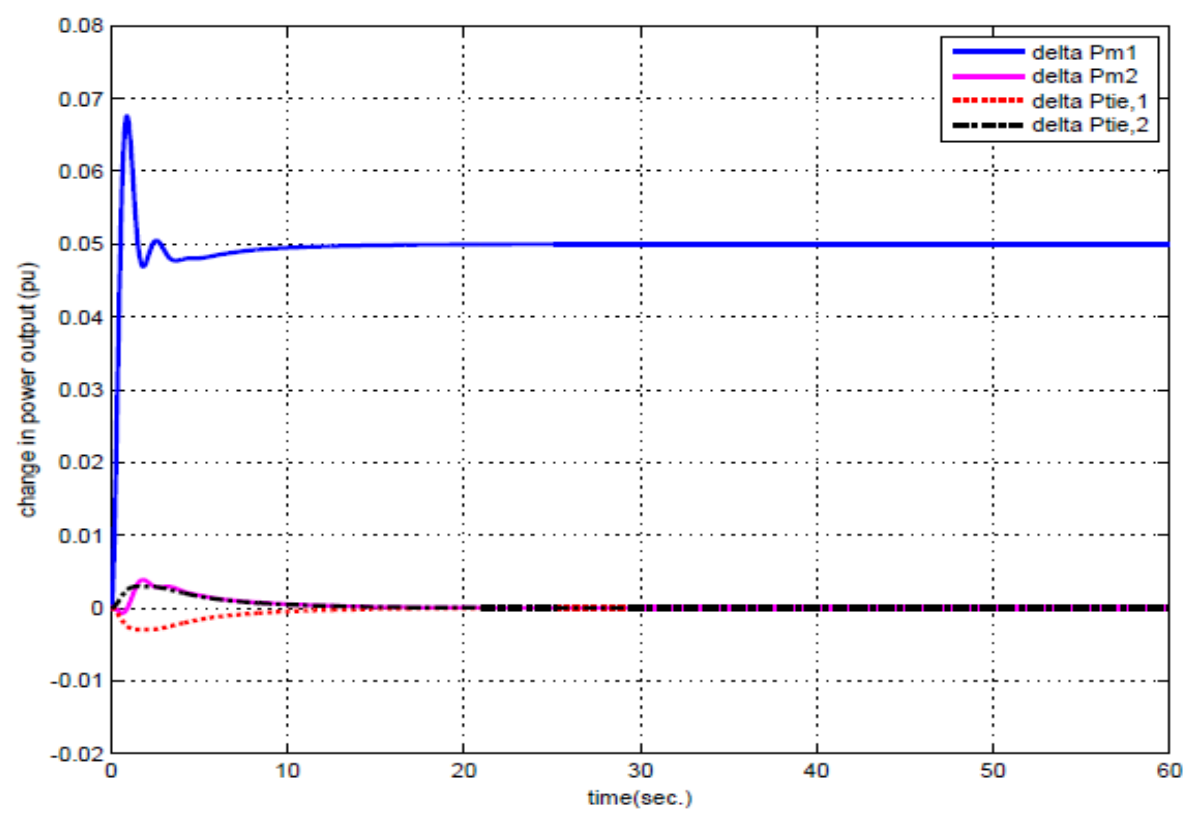

Fig.10: Change in Power output v/s time with PID

\section{CONCLUSION}

In this study, performance of I, PI and PID controller has been compared in terms of overshoot, settling time and steady state error for the frequency deviation of two area power system. PID controller gives better results with least overshoot and least settling time. It can be observed that under steady state condition, incremental turbine power output of that area in which disturbance was given, becomes equal to the load disturbance and that of other area becomes zero along with zero tie-line power deviation with these controllers. Analysis is given below in Table 1.

Table 1: Frequency deviation analysis for area-1 and area-2

\begin{tabular}{|l|l|l|l|l|}
\hline $\begin{array}{l}\text { Parameter for } \\
\Delta \mathrm{f}_{1}\end{array}$ & $\begin{array}{l}\text { Without } \\
\text { controller }\end{array}$ & With I & With PI & $\begin{array}{l}\text { With } \\
\text { PID }\end{array}$ \\
\hline $\begin{array}{l}\text { Overshoot } \\
(\mathrm{Hz})\end{array}$ & -0.22 & -0.208 & -0.190 & -0.075 \\
\hline $\begin{array}{l}\text { Settling } \\
\text { time(sec.) }\end{array}$ & 14 & 30 & 33 & 22 \\
\hline $\begin{array}{l}\text { Steady state } \\
\text { error (Hz) }\end{array}$ & -0.13 & 0 & 0 & 0 \\
\hline $\begin{array}{l}\text { Parameter for } \\
\Delta \mathrm{f}_{2}\end{array}$ & -0.033 & -0.061 & -0.054 & -0.01 \\
\hline $\begin{array}{l}\text { Overshoot } \\
\text { (Hz) }\end{array}$ & 20 & 40 & 44 & 25 \\
\hline $\begin{array}{l}\text { Settling } \\
\text { time(sec.) }\end{array}$ & -0.015 & 0 & 0 & 0 \\
\hline $\begin{array}{l}\text { Steady state } \\
\text { error (Hz) }\end{array}$ & & & & \\
\hline
\end{tabular}

\section{APPENDIX}

The Nominal system parameters are: $\mathrm{f}=50 \mathrm{~Hz}, \mathrm{~T}_{\mathrm{g} 1}=\mathrm{T}_{\mathrm{g} 2}=$ $0.4 \mathrm{~s}$,

$\mathrm{T}_{\mathrm{t} 1}=\mathrm{T}_{\mathrm{t} 2}=0.5 \mathrm{~s}, \quad \mathrm{~K}_{\mathrm{p} 1}=\mathrm{K}_{\mathrm{p} 2}=100 \mathrm{~Hz} / \mathrm{puMW}, \quad \mathrm{T}_{\mathrm{p} 1}=\mathrm{T}_{\mathrm{p} 2}=$ 20 s,
$\mathrm{R}_{1}=\mathrm{R}_{2}=3 \mathrm{~Hz} /$ puMW $, \quad \mathrm{b}_{1}=\mathrm{b}_{2}=0.425 \mathrm{puMW} / \mathrm{Hz}, \quad \mathrm{a}_{12}=-$ 1 ,

$\mathrm{K}_{\mathrm{i} 1}=\mathrm{K}_{\mathrm{i} 2}=0.2$ for $\mathrm{I}, \mathrm{K}_{\mathrm{p} 1}=\mathrm{K}_{\mathrm{p} 2}=-0.13 \& \mathrm{~K}_{\mathrm{i} 1}=\mathrm{K}_{\mathrm{i} 2}=-0.2$ for PI , $\mathrm{K}_{\mathrm{p} 1}=\mathrm{K}_{\mathrm{i} 1}=\mathrm{K}_{\mathrm{d} 1}=-1.4=\mathrm{K}_{\mathrm{p} 2}=\mathrm{K}_{\mathrm{i} 2}=\mathrm{K}_{\mathrm{d} 2}$ for PID, $\Delta \mathrm{P}_{\mathrm{L} 1}=$ $0.05 \mathrm{pu}, \Delta \mathrm{P}_{\mathrm{L} 2}=0.00 \mathrm{pu}$

\section{REFERENCES}

[1] Hadi Saadat, "Power System Analysis", McGraw-Hill companies Inc. 1999.

[2] I J Nagrath, D P Kothari , "Modern Power System Analysis", $4^{\text {th }}$ Edition.

[3] K Ogata, "Modern Control Engineering", $5^{\text {th }}$ Edition.

[4] C L Wadhwa, "Electrical Power Systems", $6^{\text {th }}$ Edition.

[5] Nilaykumar N Shah, Dwij N Mehta, Aditya D Chafekar, Anant R Suthar, "Automatic Load Frequency Control of Two Area Power System with Conventional and Fuzzy Logic Control", International Journal of Research in Engineering and Technology, vol. 01, pp. 343-347, 2012.

[6] Debirupa Hore, “An Analysis of Two Area Load Frequency Control with Different Types of Feedback Controllers", International Journal of Engineering Research \& Technology, vol. 3, pp. 922-925, 2014.

[7] Siraparapu Satyanarayana, R K Sharma, Gaur Mukta, Sappa Anil Kumar, "Automatic Generation Control in Power Plant using PID, PSS and Fuzzy-PID Controller", IEEE 2014.

[8] Prem Kumar, Mr. BSSPM Sharma, "Design and Simulation of Integral Controller Based LFC", ISORJournal of Electrical and Electronics Engineering, vol. 10, pp. 98-105, 2015.

[9] Surya Prakash, S K Sinha, “Artificial Intelligent \& PI in Load Frequency Control of Interconnected Power System", International Journal of Computer Science \& Emerging Technologies", vol. 1, pp. 377-384, 2010.

[10] Adil Usman, B P Divakar, "Simulation Study of Load Frequency Control of Single and Two Area Systems", 
IEEE Global Humanitarian Technology Conference, pp. 214-219, 2012.

[11] V Ganesh, K Vasu, P Bhavana, "LQR Based Load Frequency Controller for Two Area Power System", International Journal of Advanced Research in Electrical, Electronics and Instrumentation Engineering, vol. 1, issue- 4, pp. 262-269, 2012.

[12] Surya Prakash, S K Sinha, A S Pandey, Brijesh Singh, "Impact of Slider Gain on Load Frequency Control Using Fuzzy Logic Controller", ARPN Journal of Engineering and Applied Sciences, vol. 4, pp. 20-27, No. 7, 2009.

[13] T Bharath Kumar, M Uma Vani, "Load Frequency Control in Two Area Power System using ANFIS", Computer Engineering and Intelligent Systems, vol. 5, pp. 27-35, No. 9, 2014.

[14] Yogendra Arya, Narendra Kumar, H D Mathur, "Automatic Generation Control in Multi Area Interconnected Power System by using HVDC Links", International Journal of Power Electronics and Drive System, vol. 2, pp. 67-75, No. 1, 2012.

\section{BIOGRAPHY}

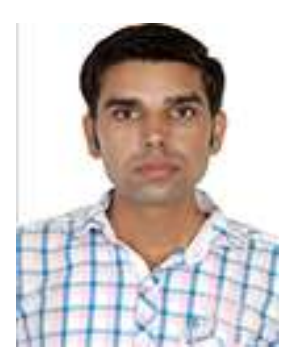

Jasmendra Singh is State Topper in Rajasthan Board in Hindi Medium School Life. He obtained $91.67 \%$ in District Board Exam in Class $8^{\text {th }}(2003$, Maths-100, Science-99, Eng. 96). He obtained $87.83 \%$ in Class $10^{\text {th }}(2005$, Science-96, Eng. 94, Maths-91) and in Class $12^{\text {th }} 86.31 \%$ in 2007 with $90 \%$ in PCM (Physics-131/150, Maths135/150, Chemistry-138/150, Eng. 86). He is AIR-19,159 in AIEEE-2009 (203/432, Eng. Med.). He received his B.Tech degree from NIT Silchar in Electrical Engineering on $12^{\text {th }}$ May 2013. He is AIR-2186 in GATE-2013 (51.67/100) with his B.Tech. He has completed his M.Tech in Power System from MNIT Jaipur in 2016. His Research interest includes Automatic Generation Control, Control System, Power Electronics, FACTS Devices, Digital Signal Processing and AI Techniques. 